\title{
EVALUATION OF CARBON MONOXIDE AND MICROPARTICLES CONCENTRATIONS GENERATED DURING MAG-C WELDING PROCESS
}

\author{
Danut Mihailescu, Marius Corneliu Gheonea, Elena Scutelnicu, Octavian Mircea
}

Preliminary communication

During the welding process, the filler wire - shielding gas couple generates the formation of pollutants which are dangerous for the welder's health. The research focussed on the quantitative evaluation of carbon monoxide (CO) and microparticles concentrations produced in MAG-C (Metal Active Gas$\mathrm{CO}_{2}$ ) welding in various process conditions. Seven welding filler wires - one common solid wire, one basic flux-cored wire, three rutile flux-cored wires and two low fume rutile flux-cored wires- were selected for the investigation and comparative analysis of the pollutants developed by melting of these wires which were deposited by welding on EH36 shipbuilding steel sheets. Applying consecutively three feed rate values, twenty-one seam welds were performed in welding horizontal position within a special hermetically air-tight chamber. Concentrations of $\mathrm{CO}$ and microparticles were acquired through special devices - Multilyzer NG of gases and MicroDust Pro for microparticles - and then were processed and comparatively discussed. Using SEM analysis, measurement of particles' size was made and discussed in detail. The images obtained by SEM illustrated the formation of amorphous structures and also nano and micro-sized particles with diameters from $641,1 \mathrm{~nm}$ to $8,92 \mu \mathrm{m}$. The investigations revealed that the lowest concentrations of $\mathrm{CO}$ and microparticles were produced when solid and low fume rutile flux-cored wires were used in the deposition welding.

Keywords: carbon monoxide; $\mathrm{CO}_{2}$ shielding gas; $M A G-C$ welding; microparticles; pollutants

Procjena koncentracije ugljičnog monoksida i mikro čestica razvijenih tijekom MAG-C postupka zavarivanja

Prethodno priopćenje Tijekom zavarivanja, dodatna žica za zavarivanje i zaštitni plin dovode do stvaranja zagađivača opasnih po zdravlje zavarivača. Istraživanje je usmjereno na kvantitativnu procjenu koncentracije ugljičnog monoksida (CO) i mikročestica kao posljedica MAG-C (Metal Active Gas- $\mathrm{CO}_{2}$ ) zavarivanja u različitim uvjetima postupka. Sedam dodatnih žica za zavarivanje - ouobičajena puna žica, osnovna, bazična žica s praškom za zavarivanje u jezgri, tri žice od rutila $\mathrm{s}$ praškom za zavarivanje u jezgri i dvije žice od rutila s praškom za zavarivanje u jezgri niskog isparavanja - izabrane su za istraživanje i komparativnu analizu zagađivača razvijenih otapanjem tih žica položenih zavarivanjem na EH36 čelične limove za brodogradilišta. Primjenjujući uzastopno tri vrijednosti brzine posmaka dobivena su dvadeset i jedan šavna zavara pri horizontalnom položaju zavarivanja unutar specijalne hermetički nepropusne komore. Koncentracije CO i mikročestica dobivene su posebnim uređajima - Multilyzer NG za plinove i MicroDust Pro za mikročestice - koje su se zatim obrađivale i o njima vodile komparativne rasprave. Mjerenje veličine čestica i detaljna rasprava provedeni su primjenom SEM analize. Slike dobivene pomoću SEMa pokazale su tvorbu amorfnih struktura i čestica nano i mikroveličina s promjerom od $641,1 \mathrm{~nm}$ do $8,92 \mu \mathrm{m}$. Istraživanja su pokazala da su najniže koncentracije $\mathrm{CO}$ i mikročestica dobivene kad su se koristile pune i žice od rutila s praškom za zavarivanje u jezgri niskog isparavanja.

Ključne riječi: ugljični monoksid; $\mathrm{CO}_{2}$ zaštitni plin; $\mathrm{MAG}$-C zavarivanje; mikročestice; zagađivači

\section{Introduction}

Welding in confined spaces can be dangerous for the welder's health because of the accumulation of high amounts of smoke, gases, dust, particulates in suspension which can seriously affect the welder's health $[1,2]$. In [3] the authors show that the processes of arc welding through fusion are accompanied by the formation of aerodisperse toxic particles $(0,005 \div 20 \mu \mathrm{m})$, commonly referred as "welding fume". Therefore, all companies involved in welding activities should be concerned about the safety, health and working conditions of their employees.

Ideally, the solution to defend the welder against the exposure to toxic and cancerous particles is to completely remove the welding fumes from the working area. Practically it is almost impossible, but specific measures are taken in order to improve the working conditions and to protect the welders against the pollutants, such as: using of welding obscured masks with air intake, filters vacuums of pollutants, welding torches provided with suction system of toxic gases and smoke [4]. On the other hand, the welding materials producers look for development of new materials which should ensure both higher productivity and lower impact on the welder's health and environment, as the authors show in [5].

Fundamental investigation into the nature of welding fumes, which were studied and characterised by means of various scientific techniques and equipment, including XRF (X-ray Fluorescence Spectrometry), NAA (Neutron Activation Analysis), XPS (X-ray Photoelectron Spectrometry), XRD (X-ray Diffraction), SEM-EDS (Scanning Electron Microscopy-Energy Dispersive Spectrometry), TEM-EDS (Transmission Electron Microscopy-Energy Dispersive Spectrometry) şi EAA (Electric Aerosol Analyzer), has been developed [6, 7]. In [6], the authors identified the main crystalline structure of the solids in welding fume and the observations made have allowed the complete description of the morphology of the welding fumes and for the definition of the relationship between the metal transfer mode and quantity of fumes generated during welding [6].

The analysis of the results achieved through the investigations conducted by researchers around the world $[3 \div 15]$ has revealed that the most influential factors on the quantity and structure of pollutants are the following:

- welding environment (outside, industrial hall, confined space)

- suction systems of gases and fumes (welding obscured masks with air intake, filters vacuums of pollutants, welding torches provided with suction system of toxic gases and smoke)

- welding position (1G-flat position, 2G-horizontal on a vertical wall/plate, $3 \mathrm{G}$-vertical up, $3 \mathrm{G}$-vertical down, 4G-overhead)

- joint type (butt and fillet welded joints) 
- $\quad$ nature of shielding gas

- $\quad$ filler wire type (solid, flux-cored)

- welding flux type (basic, rutile, metallic, selfshielded)

- $\quad$ nature of the parent material.

The main goals of the research are the improvement of knowledge related to the effects of filler metals burning on the working conditions of the welders and dissemination of the information collected in the experimental program. The paper presents the results achieved in the experimental research which was focussed on the evaluation of the maximum concentrations of $\mathrm{CO}$ and microparticles produced during the deposition of seam welds on EH36 shipbuilding steel sheets. The welds were deposited by MAG-C welding process with the following filler wires: solid wire (S1), basic flux-cored wire (B1), common and low fume rutile flow-cored wire (R1, R2, R3 and R4, R5, respectively).

\section{Experimental procedure}

Two sheets of EH36 (HSLA) shipbuilding steel with $500 \times 150 \times 14 \mathrm{~mm}$ dimensions were prepared and used in the experimental investigations. The mechanical characteristics and chemical composition of the parent metal are presented in Tab. 1 and Tab. 2. The welding filler wires with diameter of $1,2 \mathrm{~mm}$ which have been selected for investigations are listed below. The mechanical characteristics and chemical composition typical for these welding filler wires are shown in Tab. 3 and Tab. 4.

- $\quad \mathrm{S} 1$ (common solid wire) - ER70S6;

- B1 (common basic flux-cored wire) - E70T5CJH4;

- R1 (common rutile flux-cored wire) - E71T1CJH4;

- R2 (common rutile flux-cored wire) - E71T1MH4;

- R3 (common rutile flux-cored wire) - E71T1MH4;

- R4 (low fume rutile flux-cored wire) - E71T1CH8;

- R5 (low fume rutile flux-cored wire) - E71T1H4.

Using the filler wires mentioned above and applying consecutively three feed rate values, twenty-one welds were deposited on the EH36 steel sheets. Based on the experimental data acquired in the research program, a detailed comparative analysis of the filler wires' behaviour and of the pollutants generated during the burning process was made. The research equipment, designed and built in the research centre SUDAV from "Dunarea de Jos" University of Galati, is presented in Fig. 1. The steel sheet (1), on which the welds are deposited by MAG-C welding process, as well as a Railtrac FW 1000 welding tractor (3) and a PSF 315 welding torch (4) are introduced inside the hermetically air-tight chamber (15). The welding system is equipped with a swinging system (2) for the oscillation of the electric arc. Three portholes (10), (20) were designed and made in front and in the lateral of the installation in order to view and to monitor the deposition welding process.

Table 1 Mechanical characteristics of EH36 shipbuilding steel

\begin{tabular}{|c|c|c|c|c|}
\hline \multirow{2}{*}{$\begin{array}{c}\text { Parent material } \\
\text { Shipbuilding steel }\end{array}$} & Yield strength & \multicolumn{4}{|c|}{ Mechanical characteristics } \\
\cline { 2 - 5 } & $\sigma_{y} / \mathrm{MPa}$ & $\begin{array}{c}\text { Tensile strength } \\
\sigma_{\mathrm{ts}} / \mathrm{MPa}\end{array}$ & $\begin{array}{c}\text { Elongation } \\
A_{5} / \%\end{array}$ & \multicolumn{2}{c|}{ Min. KV } \\
\cline { 2 - 6 } & 550 & 426 & 27 & $77 / 84 / 89$ \\
\hline
\end{tabular}

Table 2 Chemical composition of EH36 shipbuilding steel

\begin{tabular}{|c|c|c|c|c|c|c|c|c|c|}
\hline \multirow{3}{*}{$\begin{array}{c}\text { Parent material } \\
\text { Shipbuilding steel }\end{array}$} & \multicolumn{9}{|c|}{ Chemical composition / \% } \\
\hline & $\mathrm{C}$ & Mn & $\mathrm{Si}$ & $\mathrm{P}$ & $\mathrm{S}$ & $\mathrm{Cu}$ & As & $\mathrm{Ti}$ & $\mathrm{V}$ \\
\hline & $\mathrm{Cr}$ & $\mathrm{Ni}$ & Mo & $\mathrm{Al}$ & $\mathrm{Nb}$ & $\mathrm{V}$ & $\mathrm{B}$ & $\mathrm{N}_{2}$ & $\mathrm{Ca}$ \\
\hline \multirow{2}{*}{ EH36 } & 0,152 & 1,41 & 0,36 & 0,015 & 0,006 & 0,037 & 0,004 & 0,014 & 0,001 \\
\hline & 0,03 & 0,027 & 0,003 & 0,046 & 0,03 & 0,001 & 0,0001 & 0,0065 & 0,0001 \\
\hline
\end{tabular}

Table 3 Mechanical characteristics of filler metal achived by deposition welding

\begin{tabular}{|c|c|c|c|c|c|c|}
\hline \multirow{3}{*}{ Filler wire symbol } & \multirow{3}{*}{ Filler wire type } & \multicolumn{5}{|c|}{ Mechanical characteristics } \\
\hline & & \multirow{2}{*}{$\sigma_{\mathrm{ts}} / \mathrm{MPa}$} & \multirow{2}{*}{$\sigma_{y} / \mathrm{MPa}$} & \multirow{2}{*}{$A_{5} / \%$} & \multicolumn{2}{|c|}{ Min. KV } \\
\hline & & & & & $J$ & $T /{ }^{\circ} \mathrm{C}$ \\
\hline $\begin{array}{c}\mathrm{S} 1 \\
\text { ER70S6 }\end{array}$ & solid wire & 525 & 506 & 30.4 & 117 & -20 \\
\hline $\begin{array}{c}\text { B1 } \\
\text { E70T5CJH4 }\end{array}$ & basic flux-cored wire & 520 & 430 & 28 & 120 & -40 \\
\hline $\begin{array}{c}\mathrm{R} 1 \\
\mathrm{E} 71 \mathrm{~T} 1 \mathrm{CJH} 4\end{array}$ & \multirow{3}{*}{ rutile flux-cored wire } & 594 & 548 & 24 & 70 & -20 \\
\hline $\begin{array}{c}\mathrm{R} 2 \\
\mathrm{E} 71 \mathrm{~T} 1 \mathrm{MH} 4\end{array}$ & & $530-650$ & $>470$ & $>22$ & - & -20 \\
\hline $\begin{array}{c}\text { R3 } \\
\text { E71T1MH4 }\end{array}$ & & 550 & 460 & 26 & 70 & -20 \\
\hline $\begin{array}{c}\mathrm{R} 4 \\
\mathrm{E} 71 \mathrm{~T} 1 \mathrm{CH} 8\end{array}$ & \multirow{2}{*}{$\begin{array}{l}\text { low fume rutile flux-cored } \\
\text { wire }\end{array}$} & 590 & 550 & 24 & 64 & -20 \\
\hline $\begin{array}{c}\mathrm{R} 5 \\
\text { E71T1H4 }\end{array}$ & & $530-640$ & $>460$ & $>24$ & $>70$ & -20 \\
\hline
\end{tabular}


Table 4 Chemical composition of filler metal achived by deposition welding

\begin{tabular}{|c|c|c|c|c|c|c|c|c|c|}
\hline \multirow{3}{*}{$\begin{array}{c}\text { Filler wire } \\
\text { symbol }\end{array}$} & \multirow{3}{*}{$\begin{array}{c}\text { Filler wire } \\
\text { type }\end{array}$} & \multicolumn{8}{|c|}{ Chemical composition / \% } \\
\hline & & $\mathrm{C}$ & $\mathrm{Mn}$ & $\mathrm{Si}$ & $\mathrm{P}$ & $\mathrm{S}$ & $\mathrm{Al}$ & $\mathrm{Cr}$ & $\mathrm{Ni}$ \\
\hline & & Mo & $\mathrm{V}$ & $\mathrm{Cu}$ & $\mathrm{Nb}$ & $\mathrm{N}$ & $\mathrm{B}$ & $\mathrm{Ti}$ & - \\
\hline \multirow{2}{*}{$\begin{array}{c}\text { S1 } \\
\text { ER70S6 }\end{array}$} & \multirow{2}{*}{ solid wire } & 0,065 & 1,44 & 0,825 & 0,014 & 0,008 & 0,003 & 0,025 & 0,015 \\
\hline & & 0,004 & 0,003 & 0,101 & - & - & - & - & - \\
\hline \multirow{2}{*}{$\begin{array}{c}\text { B1 } \\
\text { E70T5CJH4 }\end{array}$} & \multirow{2}{*}{$\begin{array}{l}\text { basic flux- } \\
\text { cored wire }\end{array}$} & 0,043 & 1,22 & 0,28 & 0,0087 & 0,0061 & 0,0005 & 0,0367 & 0,0106 \\
\hline & & 0,0039 & 0,0022 & 0,0564 & 0,0012 & - & - & - & - \\
\hline \multirow{2}{*}{$\begin{array}{c}\text { R1 } \\
\text { E71T1CJH4 }\end{array}$} & \multirow{6}{*}{$\begin{array}{l}\text { rutile flux- } \\
\text { cored wire }\end{array}$} & 0,049 & 1,180 & 0,379 & 0,011 & 0,010 & 0,006 & 0,041 & 0,027 \\
\hline & & 0,013 & 0,012 & 0,013 & 0,014 & 0,0037 & 0,006 & 0,034 & - \\
\hline \multirow{2}{*}{$\begin{array}{c}\text { R2 } \\
\text { E71T1MH4 }\end{array}$} & & 0,046 & 1,488 & 0,540 & 0,010 & 0,010 & - & - & - \\
\hline & & - & - & - & - & - & - & - & - \\
\hline \multirow{2}{*}{$\begin{array}{c}\text { R3 } \\
\text { E71T1MH4 }\end{array}$} & & 0,058 & 1,140 & 0,302 & 0,014 & 0,008 & 0,005 & 0,034 & 0,023 \\
\hline & & 0,005 & 0,012 & 0,094 & 0,013 & - & - & - & - \\
\hline \multirow{2}{*}{$\begin{array}{c}\text { R4 } \\
\text { E71T1CH8 }\end{array}$} & \multirow{4}{*}{$\begin{array}{l}\text { low fume } \\
\text { rutile flux- } \\
\text { cored wire }\end{array}$} & 0,026 & 1,44 & 0,51 & 0,011 & 0,013 & - & - & - \\
\hline & & - & - & - & - & - & - & - & - \\
\hline \multirow{2}{*}{$\begin{array}{c}\text { R5 } \\
\text { E71T1H4 }\end{array}$} & & 0,047 & 0,70 & 0,498 & 0,015 & 0,007 & 0,013 & 0,047 & 0,070 \\
\hline & & 0,027 & 0,018 & 0,099 & 0,016 & - & 0,007 & 0,061 & \\
\hline
\end{tabular}

The air-tight chamber is hermetically closed and has three holes (13), (17), (18) for the passage of the welding torch (40), of the digital programmable controller (11) and of the Microdust Pro device, respectively. The device for gases analysis is connected at the top of the air-tight chamber. In order to have a right view during the whole welding process, a suitable illumination was ensured

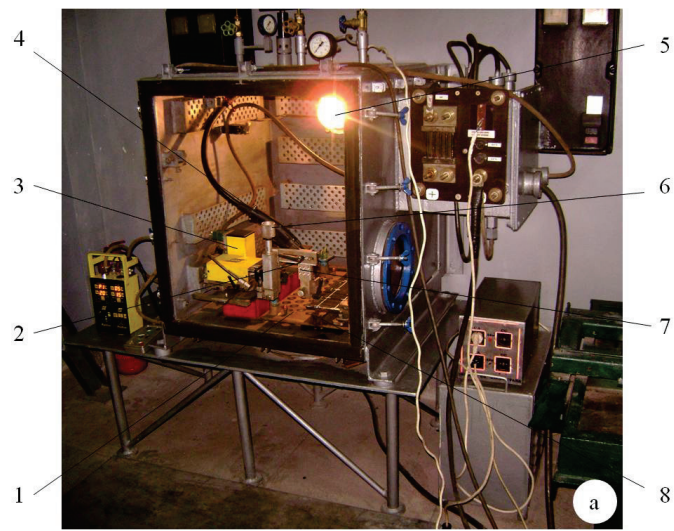

through an illumination lamp (5) which was fixed inside the air-tight chamber. Fig. 2 shows an image from inside which illustrates the positioning plan of the deposited seam welds on the EH36 steel plate. The parallelism between the steel plate and the tractor rail, as well as the distance between the sheet and the gas nozzle, were checked before starting the experiments.

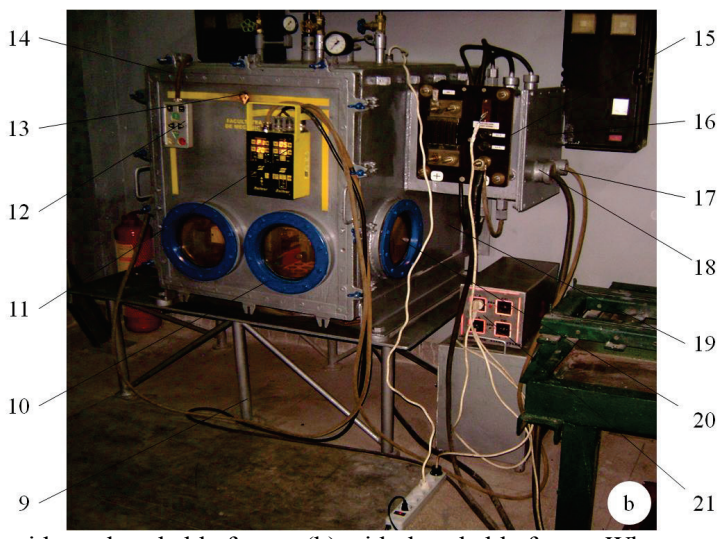

Figure 1 Equipment used in the experimental research [11 13]: (a) without detachable frame; (b) with detachable frame. Where: 1 - sheet of $500 \times 150 \times 14$ (mm) dimensions; 2 - arc swinging system; 3 - Railtrac FW 1000 welding tractor; 4 - PSF 315 welding torch; 5 - inside illumination lamp; 6 - vertical adjustment of the welding torch; 7 - swinging mechanism; 8 - copper support; 9 - supports of hermetically air-tight chamber; 10 - portholes for welding process visualisation; 11 - digital programmable controller; 12 - remote of welding system; 13 - hole for introducing of MicroDust Pro device; 14 - removable frame; 15 - air-tight chamber; 16 - hermetically air-tight chamber lid; 17 - hermetical passage for the PSF 315 torch; 18 - hermetical passage for the digital programmable controller; 19 - hermetically air-tight chamber; 20 - lateral porthole; 21 - welding power supply (42/24V AC/DC).

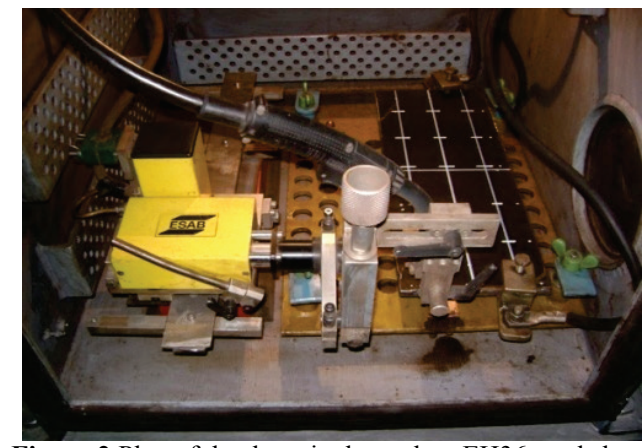

Figure 2 Plan of the deposited metal on EH36 steel sheet

The welds illustrated in Fig. 3 were synergic performed by MAG-C welding procedure in (1G) flat position, by swinging the electric arc and using $\mathrm{DC}^{+}$polarity. The main welding parameters, specific to

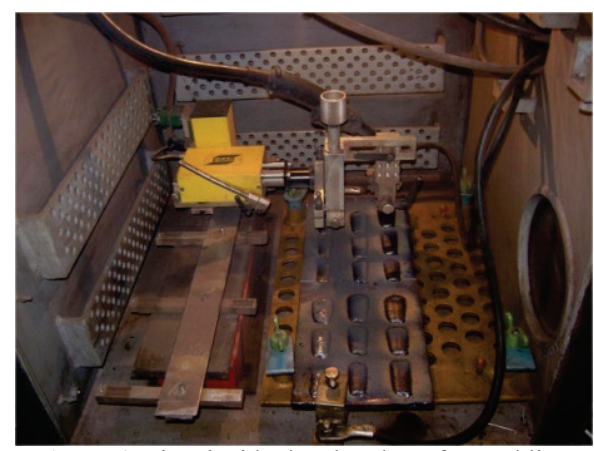

Figure 3 View inside the chamber after welding

each experimental test, were recorded by the controller unit of the Aristo Lud 320 welding equipment (Tab. 5). The welding current $\left(I_{\text {weld }}\right)$ and the welding voltage $\left(U_{\text {wa }}\right)$ were set in accordance with the filler wire type - solid 
wire (S1), basic flux-cored wire (B1), rutile flow-cored wire (R1, R2, R3) and low fume rutile flow-cored wire $(\mathrm{R} 4, \mathrm{R} 5)$ - and also with the value of the feed rate $\left(r_{\text {feed }}=\right.$ 5,$0 ; 5,5 ; 6,0 \mathrm{~m} / \mathrm{min}$ ) applied consecutively in the deposition welding process.

Several parameters shown in Tab. 6 (welding speed, swinging width, swinging speed, flow rate of shielding gas, gas flow time before starting the welding process, gas flow time after the end of the welding process, distance between sample and nozzle) were maintained constant the whole experimental program.

Table 5 Welding process variables applied in the experimental program

\begin{tabular}{|c|c|c|c|c|c|}
\hline \multirow{2}{*}{ Set no. } & \multirow{2}{*}{ Experiment no. } & \multirow{2}{*}{ Filler wire symbol } & \multicolumn{3}{|c|}{ Welding process variables } \\
\hline & & & $r_{\text {feed }} / \mathrm{m} / \mathrm{min}$ & $I_{\text {weld }} / \mathrm{A}$ & $U_{\mathrm{wa}} / \mathrm{V}$ \\
\hline \multirow{3}{*}{1} & 1 & \multirow{3}{*}{$\begin{array}{c}\text { S1 } \\
\text { ER70S6 }\end{array}$} & 5,0 & 170 & 25,5 \\
\hline & 2 & & 5,5 & 200 & 26,0 \\
\hline & 3 & & 6,0 & 230 & 26,5 \\
\hline \multirow{3}{*}{2} & 4 & \multirow{3}{*}{$\begin{array}{c}\text { B1 } \\
\text { E70T5CJH4 }\end{array}$} & 5,0 & 120 & 19,5 \\
\hline & 5 & & 5,5 & 145 & 20,0 \\
\hline & 6 & & 6,0 & 170 & 21,0 \\
\hline \multirow{3}{*}{3} & 7 & \multirow{3}{*}{$\begin{array}{c}\text { R1 } \\
\text { E71T1CJH4 }\end{array}$} & 5,0 & 130 & 20,0 \\
\hline & 8 & & 5,5 & 155 & 22,0 \\
\hline & 9 & & 6,0 & 185 & 24,0 \\
\hline \multirow{3}{*}{4} & 10 & \multirow{3}{*}{$\begin{array}{c}\mathrm{R} 2 \\
\text { E71T1MH4 }\end{array}$} & 5,0 & 130 & 20,0 \\
\hline & 11 & & 5,5 & 160 & 22,0 \\
\hline & 12 & & 6,0 & 190 & 24,0 \\
\hline \multirow{3}{*}{5} & 13 & \multirow{3}{*}{$\begin{array}{c}\text { R3 } \\
\text { E71T1MH4 }\end{array}$} & 5,0 & 130 & 20,0 \\
\hline & 14 & & 5,5 & 160 & 22,0 \\
\hline & 15 & & 6,0 & 190 & 24,0 \\
\hline \multirow{3}{*}{6} & 16 & \multirow{3}{*}{$\begin{array}{c}\mathrm{R} 4 \\
\mathrm{E} 71 \mathrm{~T} 1 \mathrm{CH} 8\end{array}$} & 5,0 & 140 & 21,0 \\
\hline & 17 & & 5,5 & 160 & 22,5 \\
\hline & 18 & & 6,0 & 180 & 24,0 \\
\hline \multirow{3}{*}{7} & 19 & \multirow{3}{*}{$\begin{array}{c}\text { R5 } \\
\text { E71T1H4 }\end{array}$} & 5,0 & 140 & 21,0 \\
\hline & 20 & & 5,5 & 165 & 22,5 \\
\hline & 21 & & 6,0 & 190 & 24,0 \\
\hline
\end{tabular}

Table 6 Welding process parameters applied in the experimental program

\begin{tabular}{|c|c|c|c|c|c|c|}
\hline \multicolumn{7}{|c|}{ Parameters maintained constant the whole experimental program } \\
\hline $\begin{array}{c}\text { Welding speed / } \\
\mathrm{cm} / \mathrm{min}\end{array}$ & $\begin{array}{c}\text { Swinging width / } \\
\mathrm{mm}\end{array}$ & $\begin{array}{c}\text { Swinging speed / } \\
\mathrm{mm} / \mathrm{s}\end{array}$ & $\begin{array}{c}\text { Flow rate of } \\
\text { shielding gas / } \\
\text { //min }\end{array}$ & $\begin{array}{c}\text { Gas flow time } \\
\text { before welding } \\
\text { process start / s }\end{array}$ & $\begin{array}{c}\text { Gas flow time } \\
\text { after welding } \\
\text { process end / s }\end{array}$ & $\begin{array}{c}\text { Distance } \\
\text { sample-nozzle / } \\
\mathrm{mm}\end{array}$ \\
\hline 20 & 15 & 5 & 18 & 3 & 3 & 15 \\
\hline
\end{tabular}
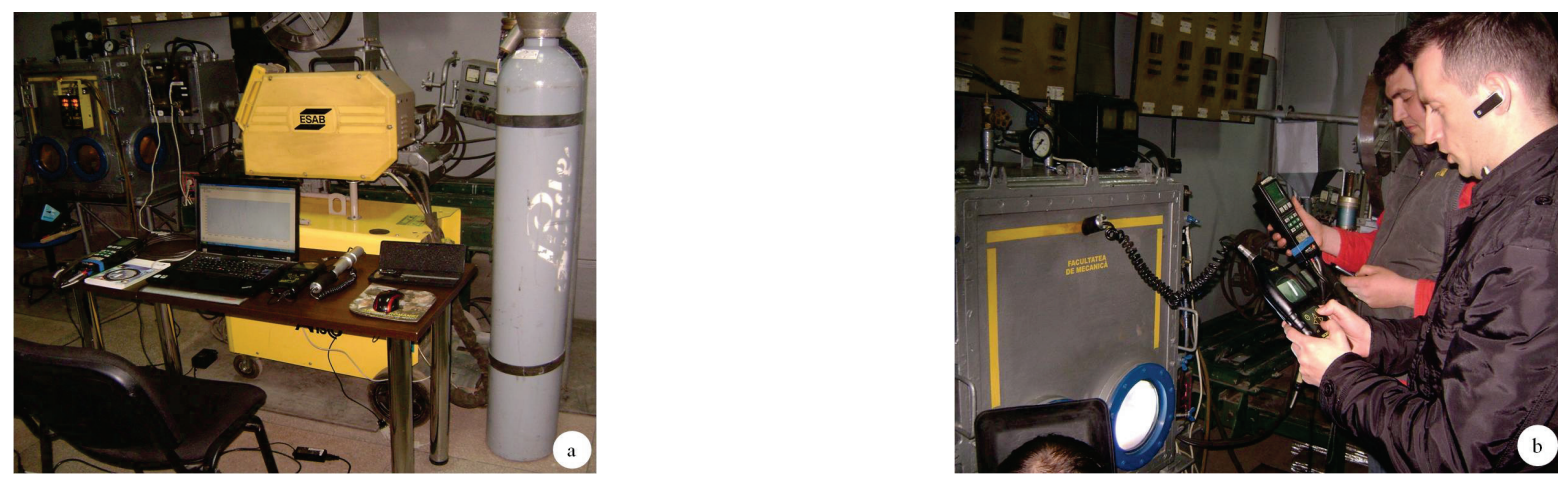

Figure 4 Experimental program phases: $\mathrm{a}$ - before starting the deposition welding process; $\mathrm{b}$ - collecting of experimental data

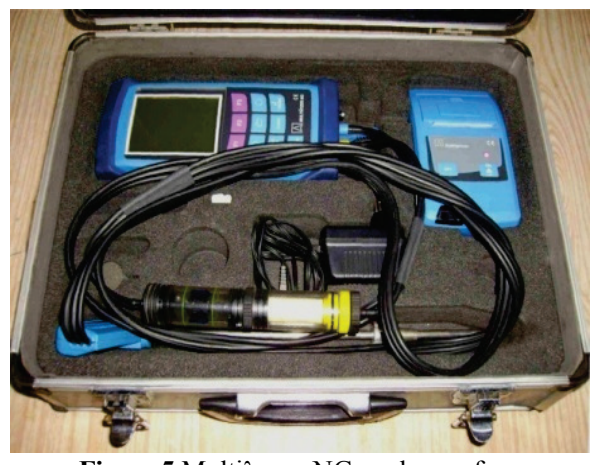

Figure 5 Multi $\lambda$ yzer NG analyser of gases

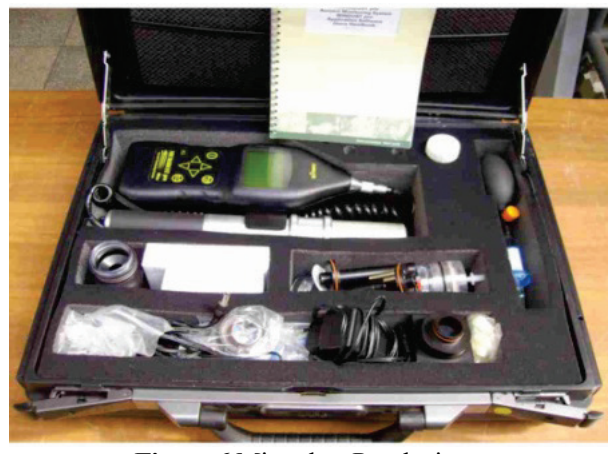

Figure 6 Microdust Pro device 
The research methodology comprises several steps: deposition welding $\rightarrow$ collecting the experimental data $\rightarrow$ processing and discussing the results. Images illustrating different phases - before starting the deposition welding process and during recording the experimental data - are shown in Fig. 4. Before performing a new seam weld, the detachable frame (14) was taken out and the air-tight chamber was ventilated by the fans fitted inside and outside the chamber, until the gases and microparticles were completely removed. In this way, the experimental results were not altered by the pollutants produced during the previous experimental test. For each seam weld, the quantitative information referred to the $\mathrm{CO}$ and microparticles concentrations has been directly measured

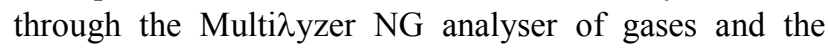

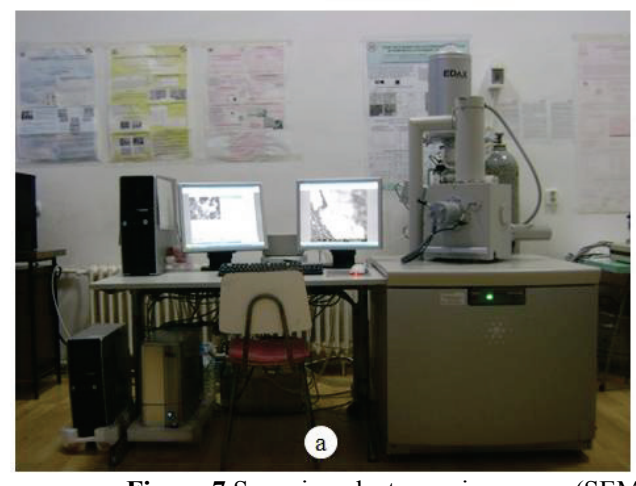

Figure 7 Scanning electron microscope (SEM/ESEM - EDAX) Quanta 200: a - general view; b - SEM analysis
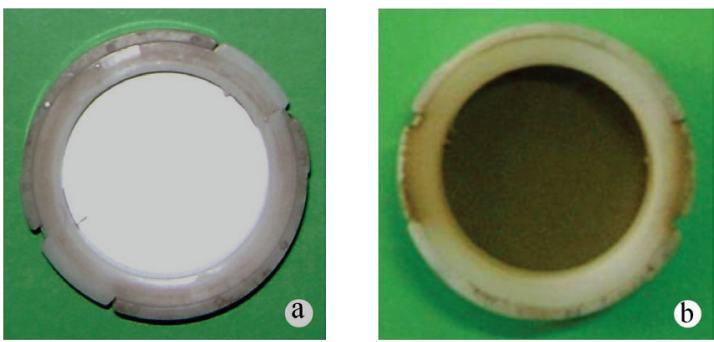

Figure 8 Glass Fiber Filter: a/b - before/after microparticles collecting

\section{Results and discussion}

The experimental data related to the concentrations of $\mathrm{CO}$ and microparticles were processed and plotted, as Figs. 9 and 10 show. It can be noticed that no matter what filler wire type (solid or flux-cored wire) and no matter what kind of flux (basic, rutile or low fume rutile) was used in the experiments, the concentration of $\mathrm{CO}$ increased with increasing the feed rate.

The comparative analysis revealed a major influence of the filler wire type on the CO concentration (Fig. 9). A ranking of the common filler wires shows an increase of $\mathrm{CO}$ concentration starting with solid wire (S1), following the basic flux-cored wire (B1), finally ending with the common rutile flux-cored wires (R1, R3, R2). In the common filler wires group, the lowest $\mathrm{CO}$ concentration (477 ppm) was achieved for the solid filler wire (S1) deposited with the lowest feed rate $(5 \mathrm{~m} / \mathrm{min})$ and the maximum CO concentration (972 ppm) was recorded in the case of rutile flux-cored wire (R2) deposited with the maximum feed rate $(6 \mathrm{~m} / \mathrm{min})$.Thus, if the solid wire (S) is replaced with common rutile flux-cored wire (R2) and the feed rate is modified from $5 \mathrm{~m} / \mathrm{min}$ to $6 \mathrm{~m} / \mathrm{min}$, the
Microdust Pro device (Fig. 5, Fig. 6). The measurement of the microparticles' diameter was made by SEM analysis. A SEM/ESEM - EDAX Quanta 200 electron microscope, presented in Fig. 7, has been used in the assessment of the microparticles' size. Special circular filters (Glass Fiber Filter Grade GF) made of glass fibre were fixed in a vacuum cleaner in order to capture the microparticles. Fig. 8 illustrates the image of the gas fibre filter before and after collecting the microparticles generated during the deposition welding. The micro particles were imprinted on carbon strips with $12 \times 12 \times 1$ [mm] dimensions which were pasted then on aluminium supports. Each carbon strip was analysed by scanning electron microscope (Enviromental Scaning Electron Microscope - ESEM mode, $60 \mathrm{~Pa}$ ).

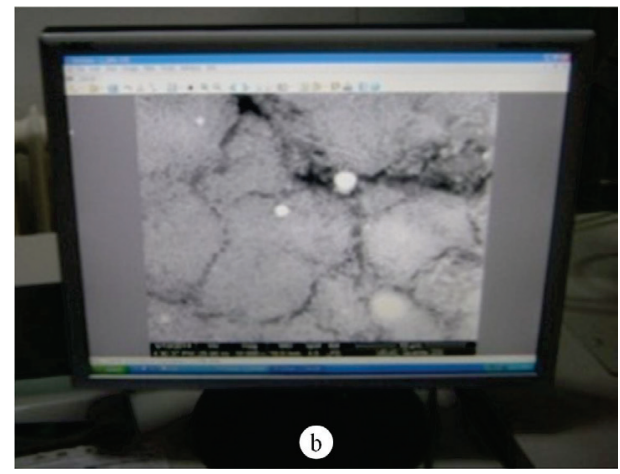

CO concentration increases by $103 \%$.

Comparing the common rutile flux-cored filler wires and the low fume rutile filler wires, lower $\mathrm{CO}$ concentrations were determined for low fume rutile filler wires. The analysis revealed that the lowest value of $\mathrm{CO}$ concentration (480 ppm) was achieved in the case of the low fume rutile filler wire (R5) melted and deposited with the lowest value feed rate $(5 \mathrm{~m} / \mathrm{min})$.

In conclusion, the analysis of $\mathrm{CO}$ showed that the solid wire (S) and the low fume rutile filler wire (R5) should be considered the safest filler wires for the welder's health, the latter filler metal ensuring also a higher productivity of the welding process.

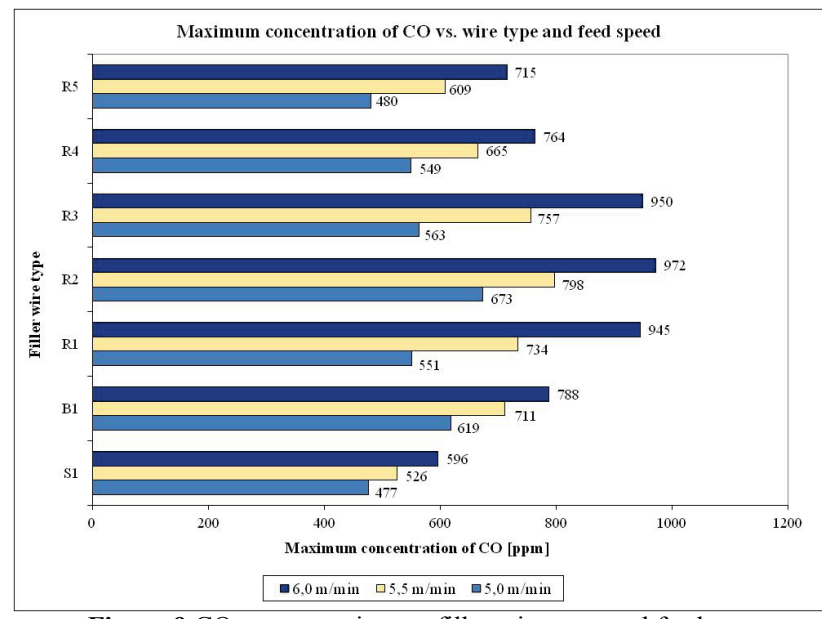

Figure $9 \mathrm{CO}$ concentration vs. filler wire type and feed rate

As regards the concentration of microparticles, the comparative analysis revealed that no matter what filler 
wire type (solid or flux-cored wire) and no matter what flux type (basic, rutile or low fume rutile) were used in the experiments, the increase of feed rate value led to the engendering of higher and higher microparticles concentrations (Fig. 10).

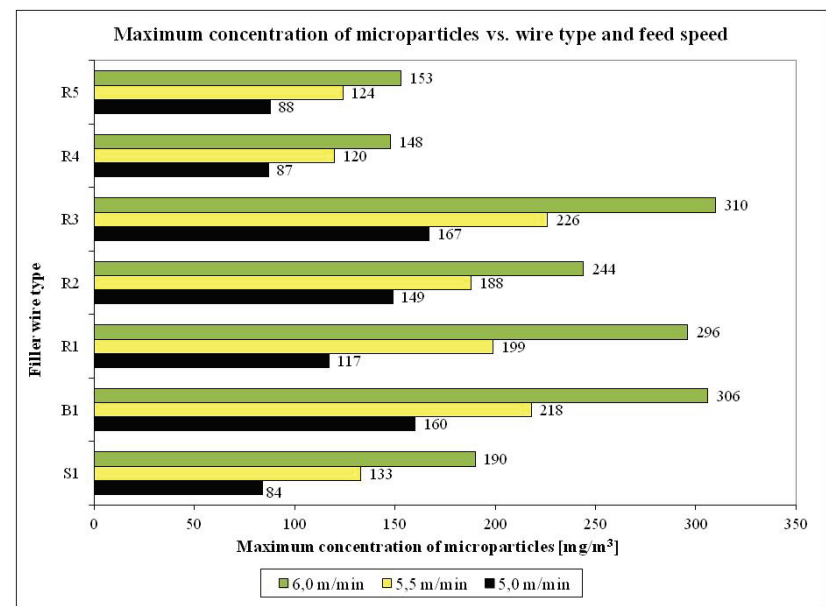

Figure 10 Microparticles concentration vs. filler wire and feed rate

As previously, the comparative analysis between the welding filler wires revealed that the type of filler metal strongly influences the concentration of microparticles. A ranking of the common filler wires from lowest to highest concentration of microparticles generated during the MAG-C welding process starts from solid wire (S1), following the basic flux-cored wire (B1), ending with the rutile flux-cored wires (R2, R1, R3). The lowest microparticles concentration $\left(84 \mathrm{mg} / \mathrm{m}^{3}\right)$ was achieved for the solid filler wire (S1) deposited with the lowest feed rate $(5 \mathrm{~m} / \mathrm{min})$. The highest concentration of microparticles $\left(310 \mathrm{mg} / \mathrm{m}^{3}\right)$ was recorded for the rutile flux-cored wire (R3) deposited with feed rate of $6 \mathrm{~m} / \mathrm{min}$, which means an increase of $269 \%$.

Comparing the common rutile filler wires (R1, R2, R3) with the low fume rutile flux-cored filler wires (R4, R5), lower microparticles concentrations have been obtained for both low fume welding filler wires (R4, R5). The lowest values of microparticles concentration (87 ppm, $88 \mathrm{ppm}$ ) were achieved when the low fume rutile filler wires (R4, R5) were deposited with the lowest feed rate $(5 \mathrm{~m} / \mathrm{min})$.

Finally, the analysis of microparticles concentration showed that solid wire (S1) and low fume rutile filler wires (R4, R5) should be considered the safest filler wires for the welder's health, the latter ensuring also a higher productivity of the welding process.

The SEM analysis revealed amorphous structures and with various nano and micro-sized particles, as the images illustrated in Figs. 11 to 17 show. The minimum and maximum diameter values, $d_{n}$ and $d_{\mu}$, are presented in Tab. 7. Excepting the common basic flux-cored wire (B1) and the common rutile flux-cored wire (R1), the wires produced nanoparticles with the diameter in the range of $641,1 \div 992,5 \mathrm{~nm}$. On the other hand, all filler wires developed micro-sized particles with diameters increasing from $1,40 \mu \mathrm{m}$ to $8,92 \mu \mathrm{m}$.

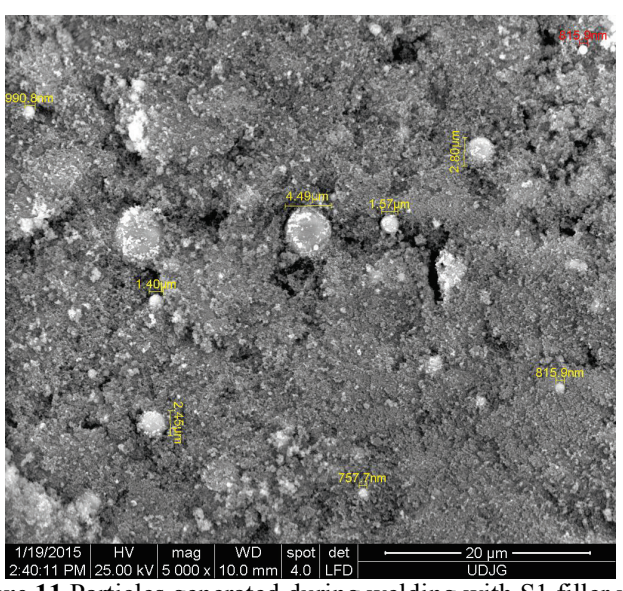

Figure 11 Particles generated during welding with S1 filler wire

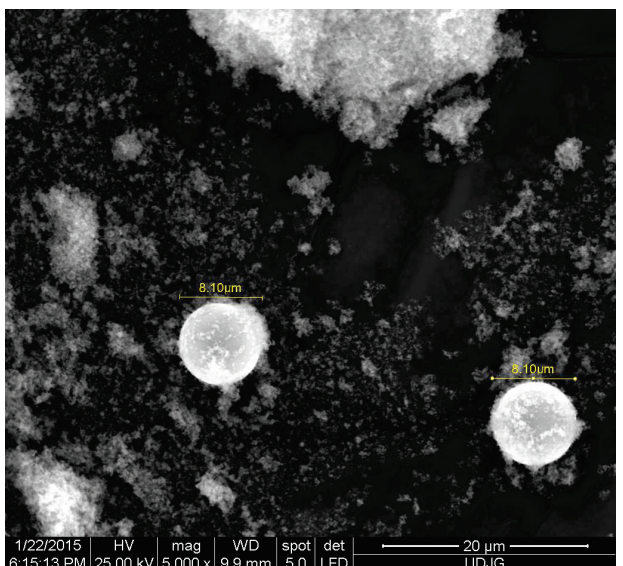

Figure 12 Particles generated during welding with B1 filler wire

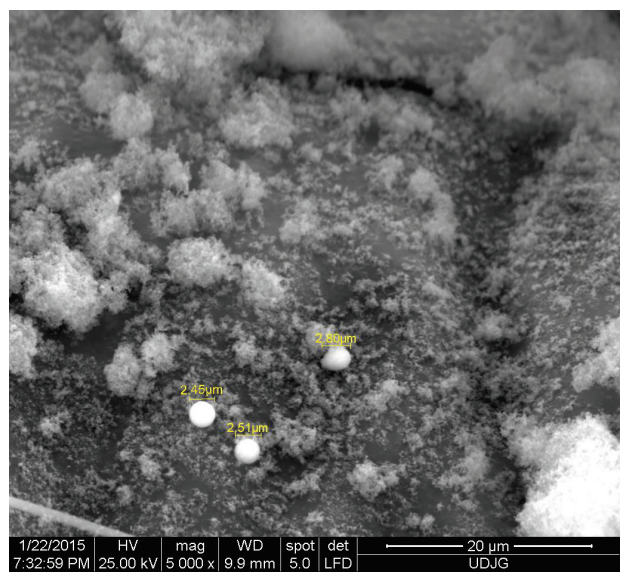

Figure 13 Particles generated during welding with R1 filler wire

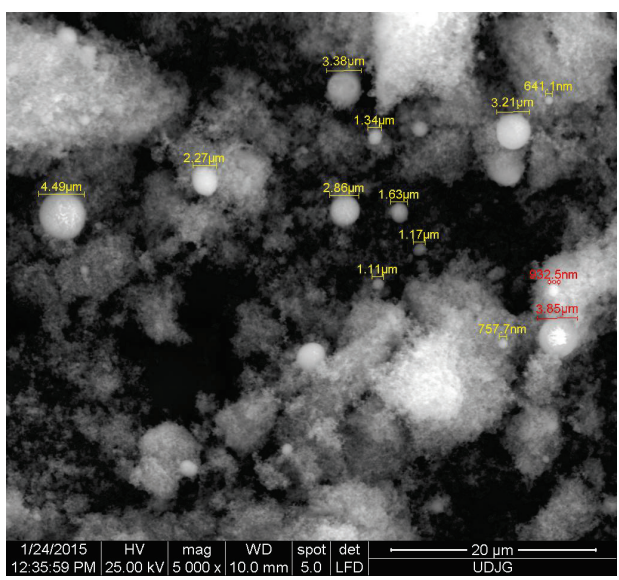

Figure 14 Particles generated during welding with R2 filler wire 


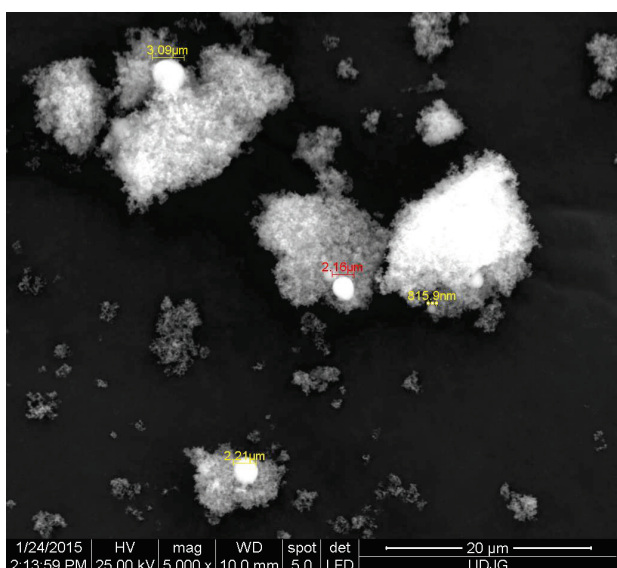

Figure 15 Particles generated during welding with R3 filler wire

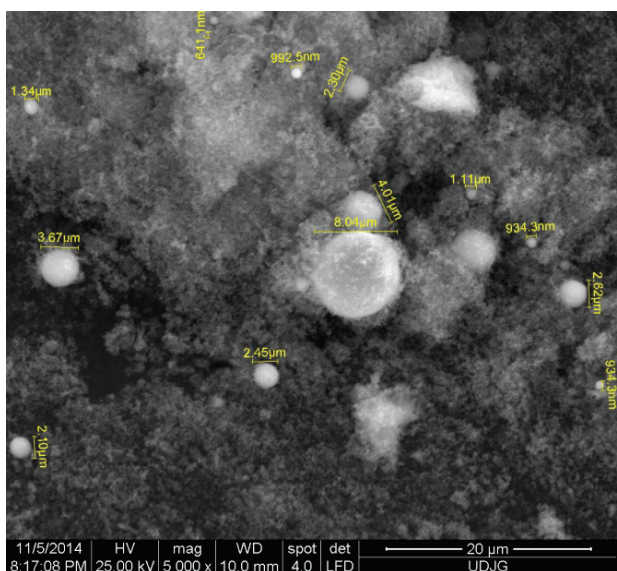

Figure 16 Particles generated during welding with R4 filler wire

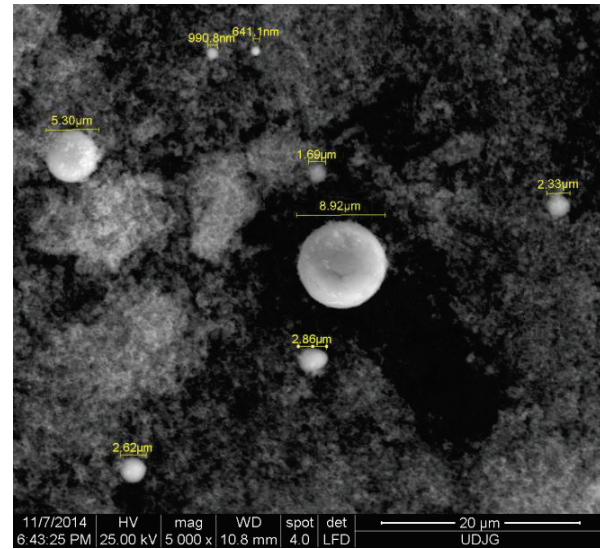

Figure 17 Particles generated during welding with R5 filler wire

Table 7 Size of particles generated during MAG-C welding process

\begin{tabular}{|c|c|c|c|c|}
\hline \multirow{2}{*}{$\begin{array}{c}\text { Welding filler } \\
\text { wire }\end{array}$} & \multicolumn{2}{|c|}{$\begin{array}{c}\text { Nanoparticles' } \\
\text { diameter, } d_{n} / \mathrm{nm}\end{array}$} & \multicolumn{2}{c|}{$\begin{array}{c}\text { Microparticles' } \\
\text { diameter, } d_{\mu} / \mu \mathrm{m}\end{array}$} \\
\cline { 2 - 5 } & $\begin{array}{c}d_{n \min } / \\
\mathrm{nm}\end{array}$ & $\begin{array}{c}d_{n \max } / \\
\mathrm{nm}\end{array}$ & $\begin{array}{c}d_{\mu \mathrm{min}} / \\
\mu \mathrm{m}\end{array}$ & $\begin{array}{c}d_{\mu \mathrm{max}} / \\
\mu \mathrm{m}\end{array}$ \\
\hline S1 - ER70S6 & 757,7 & 990,8 & 1,40 & 4,49 \\
\hline B1 - E70T5CJH4 & - & - & 8,10 & 8,10 \\
\hline R1 - E71T1CJH4 & - & - & 2,45 & 2,80 \\
\hline R2 - E71T1MH4 & 641,1 & 932,5 & 1,11 & 4,49 \\
\hline R3 - E71T1MH4 & 815,9 & 815,9 & 2,16 & 3,09 \\
\hline R4 - E71T1CH8 & 641,1 & 992,5 & 1,11 & 8,04 \\
\hline R5 - E71T1H4 & 641,1 & 990,8 & 1,69 & 8,92 \\
\hline
\end{tabular}

\section{Conclusion}

Based on the experimental results, referred to the pollutants generated by the MAG-C welding process, useful quantifiable data on the concentrations of carbon monoxide, nano and micro-sized particles produced by burning during the welding process have been achieved. The conclusions emerged from this research are synthesized below:

- No matter what filler wire type (solid or flux-cored wire) and no matter what flux type (basic, rutile or low fume rutile) were used in the experimental tests, the increase of feed rate led to the engendering of higher concentrations of pollutants.

- Particles produced by burning of welding filler wires unified and formed amorphous structures. Nano and micro-sized particles with various diameters $(641,1$ $\mathrm{nm} \div 8,92 \mu \mathrm{m}$ ) were identified by SEM analysis.

- The investigations showed that the lowest impact on the welder's health and on the environment was achieved if solid wire (S1) and low-fume rutile fluxcored wires (R4, R5) were used and the lowest feed rate was applied in the deposition welding process.

Further research will focus on the investigation of pollutants produced during MAG-M welding process and how they influence the working conditions and the impact on the environment in comparison with the pollutants developed during MAG-C welding process.

\section{Acknowledgments}

The authors are grateful to Mr. eng. Razvan Batrinu, general manager of SC Ductil SA Buzau - Romania, who kindly has provided filler materials for development of this research.

\section{References}

[1] Antonini, J. M.; Roberts, J. R.; Chapman, R. S.; Soukup, J. M.; Ghio, A. J.; Sriram, K. Pulmonary toxicity and extrapulmonary tissue distribution of metals after repeated exposure to different welding fumes. // Inhalation Toxicology. 22, 10(2010), pp. 805-816. DOl: 10.3109/08958371003621641

[2] Bowler, R. M.; Roels, H. A.; Nakagawa, S.; Drezgic, M.; Diamond, E.; Park, R.; Koller, W.; Bowler, R. P.; Mergler, D.; Bouchard, M.; Smith, D.; Gwiazda, R.; Doty, R. L. Dose-effect relationships between manganese exposure and neurological, neuropsychological and pulmonary function in confined space bridge welders. // Occupational \& Environmental Medicine. 64, 3(2007), pp. 167-177. DOI: 10.1136/oem.2006.028761

[3] Oprya, M.; Kiro, S.; Worobiec, A.; Horemans, B.; Darchuk, L.; Novakovic, V.; Ennan, A.; Van Grieken, R. Size distribution and chemical properties of welding fumes of inhalable particles. // Journal of Aerosol Science. 45, (2012), pp. 50-57. DOI: 10.1016/j.jaerosci.2011.10.004

[4] Wang, H.-Q.; Huang, C.-H.; Liu, D.; Zhao, F.-Y.; Sun, H.B.; Wang, F.-F.; Li, C.; Kou, G.-X.; Ye, M.-Q. Fume transports in a high rise industrial welding hall with displacement ventilation system and individual ventilation units. // Building and Environment. 52, (2012), pp. 119128. DOI: 10.1016/j.buildenv.2011.11.004 
[5] Leduey, B.; Galand, E.; Bauné, E.; Bonnet, C. Improvement of the welder's environment through consumable product development. // Competence, The journal of Oerlikon welding technology. 1, (2007), pp. 515.

[6] Liberati, G.; Rouault, P.; Liu, S. Investigation into welding fume formation in FCAW under $\mathrm{CO} 2$. //Competence, The journal of Oerlikon welding. 1, (2007), pp. 25-32.

[7] Stephenson, D.; Seshadri, G.; Veranth, J. M. Workplace exposure to submicron particle mass and number concentrations from manual arc welding of carbon steel. // American Industrial Hygiene Association Journal. 64, 4(2003), pp. 516-521. DOl: 10.1080/15428110308984848

[8] Carpenter, K. R.; Monaghan, B. J.; Norrish, J. Analysis of fume formation rate and fume particle composition for Gas Metal Arc Welding (GMAW) of plain carbon steel using different shielding gas compositions. // ISIJ International. 49, 3(2009), pp. 416-420. DOl: 10.2355/isijinternational.49.416

[9] Pires, I.; Quintino, L.; Miranda R. M.; Gomes, J. F. P. Fume emissions during Gas Metal Arc Welding. // Toxicological and Environmental Chemistry.88, 3(2006), pp. 385-394. DOI: 10.1080/02772240600720472

[10] Matusiak, J.; Rams, B. Emission of dust and gases in tubular cored wire welding of steel. //International Journal of Occupational Safety and Ergonomics. 9, 3(2003), pp. 333-350. DOI: 10.1080/10803548.2003.11076572

[11] Saito, H.; Ojima, J.; Takaya, M.; Iwasaki, T.; Hisanaga, N.; Tanaka, S.; Arito, H. Laboratory measurement of hazardous fumes and gases at a point corresponding to breathing zone of welder during a $\mathrm{CO}_{2}$ arc welding. // Industrial Health. 38(2000), pp. 69-78. DOI: 10.2486/indhealth.38.69

[12] Begić, R.; Imamović, A.; Halilagić, R. The impact of fume particles generated during MMAW welding with $\mathrm{Cr}-\mathrm{Ni}$ rutile electrode on the workers' health and protection. // Safety. 55, 2(2013), pp. 115-123.

[13] Amza, Gh.; Groza Dragomir, M.; Paise, S. Theoretical and experimental contributions regarding the impact on work environment of welding processes in $\mathrm{MIG} / \mathrm{MAG}$ protective gas medium. // Metalurgija. 52, 3(2013), pp. 321-324.

[14] Sowards, J. W.; Lippold, J. C.; Dickinson, D. W.; Ramirez, A. J. Characterization of welding fume from SMAWelectrodes. // Welding Journal. 87, (2008), pp. 106112.

[15] Matusiak, J.; Wycioelik, A. The influence of technological conditions on the emission of welding fume due to welding of stainless steels. // Metalurgija. 49, 4(2010), pp. 307-311.

\section{Authors' addresses}

Prof. Danut Mihailescu, PhD

"Dunarea de Jos" University of Galati, Faculty of Engineering, Department of Manufacturing Engineering 47 Domneasca St., Galati, Romania

E-mail: danut.mihailescu@ugal.ro

Assist. Prof. Marius Corneliu Gheonea, PhD

"Dunarea de Jos" University of Galati, Faculty of Engineering Department of Manufacturing Engineering

47 Domneasca St., Galati, Romania

E-mail: marius.gheonea@ugal.ro

\section{Prof. Elena Scutelnicu, PhD}

Corresponding author

"Dunarea de Jos" University of Galati, Faculty of Engineering Department of Manufacturing Engineering

47 Domneasca St., Galati, Romania

E-mail: elena.scutelnicu@ugal.ro

\section{Assoc. Prof. Octavian Mircea, PhD}

"Dunarea de Jos" University of Galati, Faculty of Engineering, Department of Manufacturing Engineering

47 Domneasca St., Galati, Romania

E-mail: octavian.mircea@ugal.ro 